\title{
PELATIHAN PEMBUATAN PAKAN FERMENTASI DAN APLIKASI PROBIOTIK UNTUK ITIK PETELUR DI DESA KEBONSARI SIDOARJO
}

\author{
Oleh: \\ Anggi Putra Dharmawan ${ }^{1}$, Arni Al Hikmah Putri', Mochammad Nurwahyudi ${ }^{3}$, Fifi Afifah $^{4}$ \\ 1,2,3,4 Jurusan Kimia FMIPA Unesa \\ 1anggidharmawan@mhs.unesa.ac.id
}

\begin{abstract}
Abstrak
Desa Kebonsari merupakan satu-satunya lokasi Desa di Sidoarjo yang memberdayakan peternakan bebek. Potensi ini juga diiringi dengan adanya limbah ternak yang salah satunya berupa bau yang tidak sedap sehingga perlu adanya penanganan. Hal tersebut dapat ditangani dengan menggunakan probiotik, baik secara oral (untuk makanan) maupun disemprotkan pada kandang. Tujuan dari pengabdian yang dilakukan yaitu untuk mengetahui tingkat pemahaman warga Desa Kebonsari, khususnya peternak itik mengenai probiotik dan meningkatkan mutu peternakan di Desa Kebonsari dilihat dari aspek kebersihan dan kesehatan.. Hal ini disebabkan karena kurangnya pengetahuan peternak itik di daerah tersebut untuk mengurangi bau dari kotoran ternak. Langkah yang dilakukan yaitu dengan melakukan sosialisasi cara pembuatan dan demonstrasi serta melakukan monitoring dan evaluasi. Didapatkan bahwa $80 \%$ peternak telah memiliki keterampilan dalam pembuatan pakan itik, $80 \%$ menyatakan bau kotoran menjadi berkurang dengan baik, dan $80 \%$ menyatakan kesehatan itik mengalami peningkatan. Berdasarkan hal tersebut dapat disimpulkan bahwa probiotik yang digunakan efektif untuk mengurangi bau kotoran dan menjaga kesehatan ternak.
\end{abstract}

Kata Kunci: probiotik, bau kotoran ternak, peternak itik

\begin{abstract}
Kebonsari village is the only one location in Sidoarjo that empowers duck farms. This potential is also accompanied by the presence of livestock wastes, one of which is a bad odor that needs handling. It can be handled using probiotics, either orally (for food) or sprayed on the cage. The purposes of this dedication is to find out the level of understanding of Kebonsari villagers, especially ducks breeders on probiotics and improve the quality of dairy farms in the village Kebonsari seen from the aspects of cleanliness and health. This is due to the lack of knowledge of duck breeders in the area to reduce the smell of cattle dung. The steps taken are to socialize the way of making and demonstration and monitoring and evaluation. It was found that $80 \%$ of breeders have skill in duck feeding, $80 \%$ said the smell of dirt was reduced significantly, and $80 \%$ said duck health improved. Based on this it can be concluded that probiotics are used effectively to reduce the smell of dirt and maintain the health of livestock.
\end{abstract}

Keywords: probiotics, the smell of cattle dung, duck breeder

\section{PENDAHULUAN}

Wilayah Desa Kebonsari selain sebagai areal pemukiman, juga dimanfaatkan sebagai areal pertanian, peternakan dan wisata pangan. Jenis ternak yang ada di Desa Kebonsari sebagian besar adalah hewan unggas bebek. Potensi peternakan bebek petelur yang ada pada Desa Kebonsari Kecamatan Candi Kabupaten Sidoarjo sangat potensial karena ditunjang oleh lingkungannya yang banyak lahan luas dengan luas pekarangan sebesar $86,65 \mathrm{Ha}$ dan lokasi strategis yang dekat dengan jalur jalan Surabaya-Malang. Namun saat musim hujan banyak lahan luas yang tergenang banjir, sehingga ternak mudah stres dan terserang penyakit. Kondisi ini diperparah dengan keadaan dimana kebanyakan bebek dipelihara dekat dengan pemukiman warga yang menyebabkan limbah berupa kotoran sehingga ketika banjir atau turun hujan deras limbah kotoran akan menggenang.

Kehadiran limbah ternak dengan konsentrasi dan kuantitas tertentu dapat berdampak negatif terhadap lingkungan dan kesehatan manusia, diantaranya menghasilkan bau yang kurang sedap, tidak enak dipandang, bahkan dapat menjadi faktor penyebab penyakit terhadap hewan ternak maupun masyarakat sekitar sehingga perlu dilakukan penanganan untuk mengurangi dampak-dampaknya, namun karena 
kurangnya pengetahuan menyebabkan masyarakat desa ini mengesampingkan dampak dari limbah tersebut dan membiarkan bau kurang sedap dari kotoran ternak itu meskipun dapat menjadi faktor penyebab berbagai penyakit. Bau menyengat pada kotoran unggas terjadi akibat metabolisme ditubuh unggas kurang sempurna. Metabolisme yang tidak sempurna menyebabkan banyak nutrisi pakan yang tidak tercerna, khususnya protein. Gugus amino pada protein dapat berubah gas-gas kimia yang berbahaya seperti amoniak (Isshiki, 1979).

Tujuan dari pengabdian yang dilakukan yaitu untuk mengetahui tingkat pemahaman warga Desa Kebonsari, khususnya peternak itik mengenai probioti dan meningkatkan mutu peternakan di Desa Kebonsari dilihat dari aspek kebersihan dan kesehatan. Probiotik merupakan suatu produk yang mengandung mikroba hidup non patogen yang diberikan kepada ternak untuk memperbaiki laju pertumbuhan, efisiensi konversi ransum dan kesehatan ternak (Stark dan Wilkinson, 1989).

Rencana untuk mengatasi permasalahan di atas yaitu dengan studi lapangan untuk mengetahui kondisi peternakan, menjalin kerja sama, studi literatur untuk pembuatan materi sosialisasi dan modul, ujicoba probiotik secara mandiri sebelum melakukan sosialisasi, sosialisasi kepada peternak itik, pendampingan pembuatan probiotik, serta monitoring dan evaluasi pada kondisi ternak dan bau yang dihasilkan.

\section{METODE}

Metode yang digunakan dalam melaksanakan program ini dengan sistem learning by doing dengan bantuan media ajar berupa modul dan materi presentasi. Kegiatan pertama adalah sosialisasi yang berisi pemberian materi tentang pendahuluan probiotik, pemanfaatan probiotik, dan cara pembuatan pakan fermentasi dari dedak padi. Setelah dilakukan sosialisasi mengenai materi, kegiatan kedua yaitu penyiapan alat dan bahan serta kegiatan demonstrasi cara pembuatan pakan fermentasi dari dedak padi.

Demonstrasi atau peragaan tentang: Teknik pembuatan pakan fermentasi dan pemberian probiotik. Pakan itik dibuat dengan cara fermentasi campuran dedak padi, tepung jagung, tepung ikan, dan sayuran dengan perbandingan 4:3:2:1. Kemudian ditambahkan dengan gula pasir sebanyak 100 gram dan probiotik sebanyak 20 tutup botol (setiap pembuatan $100 \mathrm{~kg}$ pakan). Probiotik yang akan digunakan adalah didapatkan secara komersil dengan merk dagang EM-4 dan starbio yang kaya akan bakteri asam laktat.

Setelah demonstrasi dilakukan, terdapat sesi tanya jawab untuk memperjelas materi dan pemahaman peternak itik. Setelah dilakukan demonstrasi yang dilakukan oleh mahasiswa, kegiatan ketiga yaitu kegiatan percobaan secara langsung yang dilakukan oleh warga peternak. Kegiatan terakhir yaitu monitoring dan evaluasi.

Evaluasi terhadap kegiatan ini dilakukan 3 tahap :

a. Tahap I, dilakukan dengan cara pengisian angket yang berisi pertanyaan. Kegiatan ini dilaksanakan sebelum kegiatan pemberian materi dimulai dengan tujuan untuk mengetahui tingkat pengetahuan peserta tentang probiotik, teknik pembuatan pakan fermentasi, dan cara penggunaan probiotik (pretest).

b. Tahap II, evaluasi tahap II dilakukan setelah kegiatan penyuluhan dan demonstrasi dilaksanakan, dengan tujuan untuk mengetahui sampai sejauh mana daya serap dan minat peserta terhadap materi penyuluhan dan peragaan yang telah dilakukan (posttest).

c. Tahap III, evaluasi tahap III dilakukan setelah kegiatan pengabdian berakhir. Kegiatan ini bertujuan untuk mengetahui kemampuan peserta melaksanakan sendiri bagaimana cara pembuatan pakan fermentasi dan pemberian penggunaan probiotik serta bagaimana pengaruhnya terhadap bau kotoran ternak itik, serta dilakukan uji organoleptik terhadap feses itik yang diberi probiotik dan tanpa diberi probiotik melalui pengisian angket.

Jika digambarkan dalam bentuk diagram alir, maka metode yang kami lakukan adalah sebagai berikut.

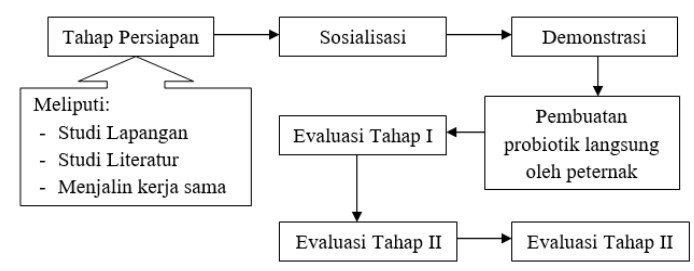

Gambar 1. Diagram Alir Metode Pelaksanaan Pengabdian 


\section{HASIL DAN PEMBAHASAN}

Hasil diskusi dan survei yang dilakukan deng Hasil yang dicapai mengacu pada indikator keberhasilan jangka pendek, selama pelaksanaan kegiatan pengabdian kepada masyarakat yang dapat dilihat dari kesesuaian jenis dan jumlah luaran yang telah dihasilkan serta persentase hasil terhadap keseluruhan target kegiatan. Tentunya dalam pelaksanaan kegiatan yang telah dilakukan seperti yang ditunjukkan pada Gambar 2 terdapat perubahan kegiatan maupun penambahan kegiatan, akan tetapi hal tersebut dapat diselesaikan dengan koordinasi dan konsultasi bersama pihakpihak yang terkait.

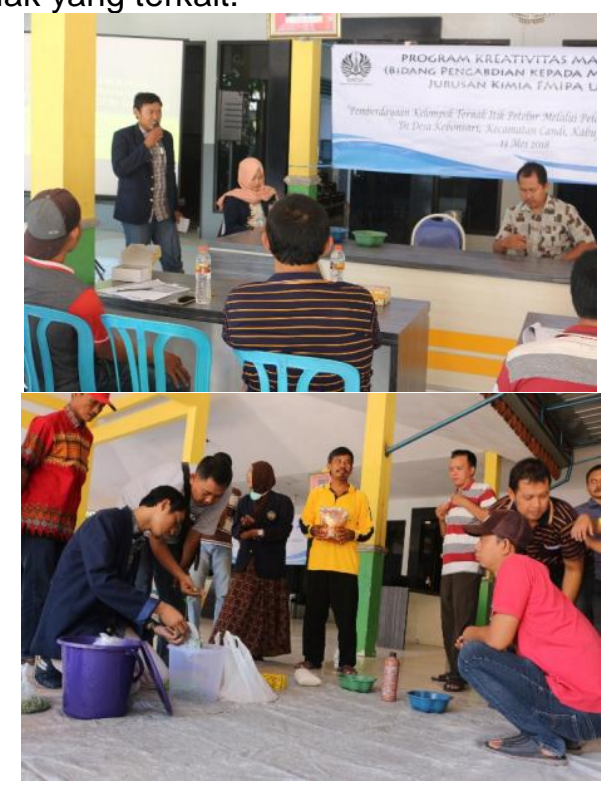

Gambar 2. Presentasi dan proses pembuatan probiotik

Berikut ini merupakan hasil yang dicapai selama pelaksanaan kegiatan sebagai berikut.

1. Menambah wawasan dan ilmu pengetahuan bagi warga peternak

Berdasarkan pelaksanaan kegiatan pengabdian dalam rangka menambah wawasan dan ilmu pengetahuan bagi warga setempat perlu dilihat keberhasilannya dari indikator-indikator keberhasilan melalui angket kuisioner yang diberikan sebelum dan sesudah penyajian materi. Dari 12 responden yang mengisi kuisioner pretest (sebelum penyajian materi), hasil menunjukkan $83 \%$ belum mengetahui tentang probiotik, $67 \%$ belum mengetahui pakan fermentasi, dan $75 \%$ belum pernah membuat pakan fermentasi.

Setelah pengisian kuisioner pretest, warga peternak disajikan materi mengenai probiotik dan pakan fermentasi. Setelah kegiatan penyuluhan dan demonstrasi, diberi kuisioner posttest. Dari 12 responden yang mengisi kuisioner, hasil pada Tabel 1 menunjukkan secara garis besar dari hasil angket tersebut hanya disajikan nilai persentasi yang paling besar dari poin $1-5$, serta menunjukkan hasil bahwa program kegiatan ini telah berhasil dengan persentasi lebih dari sama dengan $50 \%$. Hanya saja pada kepuasan mengenai modul masih belum baik.

2. Dapat menciptakan sebuah peternakan itik petelur yang ramah lingkungan

Indikator keberhasilan yang dapat dijadikan tolok ukur keberhasilan program ini adalah keterampilan warga dalam membuat pakan fermentasi, pengurangan bau pada kandang, dan kesehatan itik menjadi meningkat. Dari 5 responden yang mengisi kuisioner hasil evaluasi dengan poin $1-5$, sebanyak $80 \%$ menyatakan sudah memiliki keterampilan dalam pembuatan pakan fermentasi dengan skor 2 yang berarti kurang. Sebanyak $80 \%$ menyatakan bau kotoran menjadi berkurang dengan skor 4 yang berarti baik. Sebanyak $80 \%$ menyatakan kesehatan itik menjadi meningkat dengan skor 4 yang berarti baik. Dari hasil evaluasi tersebut, dapat dilihat bahwa program ini bisa menjadikan peternak Desa kebonsari sebagai percontohan bagi peternakan lain dalam hal mewujudkan peternakan yang ramah lingkungan. Namun, terdapat skor angka 2 yang lebih dominan yaitu pada ketrampilan dalam pembuatan pakan fermentasi. Hal tersebut dikarenakan kurangnya warga masyarakat untuk menerapkan pembuatan pakan fermentasi sendiri. Masyarakat mampu mengurangi bau pada ternaknya hanya melalui aplikasi probiotik dengan cara menyemprotkan pada kandang. 
Tabel 1. Kuisioner Posttest

\begin{tabular}{|c|c|c|}
\hline No. & Uraian & Hasil persentase \\
\hline 1. & Materi yang sudah disampaikan & $\begin{array}{l}\text { Sebanyak } 58,33 \% \text { menyatakan } \\
\text { materi disampaikan dengan skor } 4 \\
\text { yang berarti baik }\end{array}$ \\
\hline 2. & Materi sesuai topik pelatihan & $\begin{array}{l}\text { Sebanyak } 66,67 \% \text { menyatakan } \\
\text { materi sesuai topik pelatihan dengan } \\
\text { skor } 4 \text { yang berarti baik }\end{array}$ \\
\hline 3. & Susunan materi yang sistematis & $\begin{array}{l}\text { Sebanyak } 50 \% \text { menyatakan } \\
\text { susunan materi yang sistematis } \\
\text { dengan skor } 4 \text { yang berarti baik }\end{array}$ \\
\hline 4. & $\begin{array}{l}\text { Hubungan materi yang disajikan dengan } \\
\text { kebutuhan Masyarakat }\end{array}$ & $\begin{array}{l}\text { Sebanyak } 58,33 \% \text { menyatakan } \\
\text { hubungan materi yang disajikan } \\
\text { dengan kebutuhan Masyarakat } \\
\text { dengan skor } 4 \text { yang berarti baik }\end{array}$ \\
\hline 5. & $\begin{array}{l}\text { Materi meningkatkan pengetahuan dan } \\
\text { kemampuan terkait tentang probiotik dan } \\
\text { pakan fermentasi }\end{array}$ & $\begin{array}{l}\text { Sebanyak } 50 \% \text { menyatakan materi } \\
\text { dapat meningkatkan pengetahuan } \\
\text { dengan skor } 4 \text { yang berarti baik }\end{array}$ \\
\hline 6. & Pemateri dan teknik penyajian & $\begin{array}{l}\text { Sebanyak } 58,33 \% \text { menyatakan } \\
\text { pemateri dan teknik penyajian } \\
\text { dengan skor } 4 \text { yang berarti baik }\end{array}$ \\
\hline 7. & $\begin{array}{l}\text { Modul pelatihan dan materi yang } \\
\text { bermanfaat }\end{array}$ & $\begin{array}{l}\text { Sebanyak } 33,33 \% \text { menyatakan } \\
\text { modul pelatihan dengan skor } 4 \text { yang } \\
\text { berarti baik }\end{array}$ \\
\hline 8. & Minat anda terhadap kegiatan ini & $\begin{array}{l}\text { Sebanyak } 50 \% \text { menyatakan minat } \\
\text { terhadap kegiatan dengan skor } 4 \\
\text { yang berarti baik }\end{array}$ \\
\hline
\end{tabular}

Hasil kuisioner evaluasi yang menyatakan bahwa bau kotoran pada ternak sudah berkurang dengan baik, perlu didukung dengan data lain yakni uji organoleptik pada feses itik petelur yang tanpa diberi perlakuan dengan yang diberikan probiotik. Hasil menunjukkan secara fluktuatif dari segi penampakan/bentuk, aroma/bau, dan warna menunjukkan tingkat kepuasan terhadap feses dari itik dengan perlakuan penambahan probiotik hasilnya lebih memuaskan dibandingkan dengan feses dari itik tanpa perlakuan. Selain itu dilakukan uji biuret secara kualitatif untuk membuktikan adanya protein dalam feses itik. Hasil menunjukkan bahwa warna ungu pada feses dari itik tanpa perlakuan lebih pekat. Hal ini menandakan kadar protein pada feses dari itik tanpa perlakuan lebih besar daripada feses dari itik dengan perlakuan penambahan probiotik. Probiotik yang mengandung bakteri baik akan membuat kerja saluran pencernaan lebih sempurna sehingga lebih sedikit nutrisi yang terbuang di kotoran unggas termasuk protein. Sesuai angket evaluasi yang menunjukkan kepuasan terhadap berkurangnya bau kotoran pada ternak, dengan didukung oleh uji organoleptik dan uji biuret yang dilakukan dapat dikatakan bahwa program ini telah berhasil mewujudkan peternakan itik petelur yang ramah lingkungan. Ketercapaian target luaran dari program "Blusukan Kampoeng Bebek" yang dilaksanakan di Desa Kebonsari, Kecamatan Candi, Kabupaten Sidoarjo ditunjukkan pada Tabel 2. 
Tabel 2. Ketercapaian Target Luaran

\begin{tabular}{clcc}
\hline \multirow{2}{*}{ No. } & \multicolumn{1}{c}{ Target } & \multicolumn{2}{c}{ Ketercapaian (100\%) } \\
\cline { 3 - 4 } & \multicolumn{1}{c}{ Terlaksana } & Belum Terlaksana \\
\hline 1. & Survei lapangan di Desa Kebonsari & $100 \%$ & - \\
\hline 2. & $\begin{array}{l}\text { Mengurus perizinan dan kerjasama } \\
\text { dengan mitra }\end{array}$ & $100 \%$ & - \\
\hline 3. & Persiapan perlengkapan kegiatan & $100 \%$ & - \\
\hline 4. & $\begin{array}{l}\text { Sosialisasi dan Pelatihan kepada } \\
\text { warga }\end{array}$ & $100 \%$ & $40 \%$ \\
\hline 5. & Partisipasi warga dalam kegiatan & $60 \%$ & $50 \%$ \\
\hline 6. & $\begin{array}{l}\text { Kemampuan warga dalam } \\
\text { mengaplikasikan materi dalam kegiatan }\end{array}$ & $50 \%$ & $20 \%$ \\
\hline 7. & $\begin{array}{l}\text { Kebermanfaatan kegiatan ini dalam } \\
\text { mewujudkan peternakan yang ramah } \\
\text { lingkungan }\end{array}$ & $80 \%$ & $40 \%$ \\
\hline 8. & $\begin{array}{l}\text { Penyusunan laporan kegiatan, artikel, } \\
\text { laporan akhir, dan bukti pendukung } \\
\text { lain-lain }\end{array}$ & $60 \%$ & \\
\hline
\end{tabular}

\section{SIMPULAN DAN SARAN}

Simpulan dari pembahasan di atas antara lain sebagai berikut:

1. Pengabdian ini dapat memberikan wawasan kepada warga Desa Kebonsari, khususnya peternak itik mengenai probiotik.

2. Pengabdian ini dapat menciptakan peternakan itik petelur yang ramah lingkungan.

\section{Saran}

Perlu adanya pelatihan berkelanjutan untuk fokus pada produktivitas telur dari itik petelur yang diberi pakan fermentasi.

\section{DAFTAR PUSTAKA}

Husmaini, dkk. (2017). Pengembangan Usaha Itik Lokal Sumber Daya Genetik Sumatera Barat yang Bebas Flu Burung melalui introduksi Probiotik dan Penetasan Buatan untuk menghasilkan Bibit dan Produk Rendah Kolesterol Di Kabupaten Tanah Datar. Padang: Fakultas Peternakan Universitas Andalas Padang.

Isshiki, Y. (1979). Effect of lactobacili in the diet on the concentration of nitrogenus chikens. Japanese Poultry Sci. 16:254258.
Mangisah, Istnah dan Bambang Sukamto. (2017). Pelatihan Budidaya Itik Secara Semi Intensif Dan Penetasan Telur Di Desa Kebakalan Banjarnegara. Jurnal Info. Semarang: Fakultas Peternakan dan Pertanian Universitas Diponegoro.

Stark, B.A. and J.M. Wilkinson. (1989). Probiotics: Theory and application. Chalcombe Publications Berks, England.

Zurmiati, M. E. Mahata, M. H. Abbas, Wizna. (2014). Aplikasi Probiotik untuk Ternak Itik. Jurnal Peternakan Indonesia. Padang: Fakultas Peternakan Universitas Andalas. 